\title{
Peer Review of "Information Technology Ambidexterity, Digital Dynamic Capability, and Knowledge Processes as Enablers of Patient Agility: Empirical Study"
}

\author{
Joseph Walsh, MSc
}

School of Health Information Science, University of Victoria, Victoria, BC, Canada

\section{Related Articles:}

Preprint (medRxiv): https://www.medrxiv.org/content/10.1101/2021.07.20.21260841v1

Preprint (JMIR Preprints): https://preprints.jmir.org/preprint/32336

Authors' Response to Peer-Review Reports: https://med.jmirx.org/2021/4/e34106/

Published Article: https://med.jmirx.org/2021/4/e32336/

(JMIRx Med 2021;2(4):e34110) doi: 10.2196/34110

\section{KEYWORDS}

IT ambidexterity; dynamic capabilities; digital dynamic capability; knowledge processes; patient agility; hospitals; Information sciences; Information technology; digital health; healthcare; digital transformation; research models

This is a peer veview of "Information Technology Ambidexterity, Digital Dynamic Capability, and Knowledge Processes as Enablers of Patient Agility: Empirical Study"

\section{Round 1 Review}

\section{General Comments}

Thank you for the opportunity to review this paper [1] on the lesser known topic of information and communications technology ambidexterity. The paper is well cited, uses appropriate methods, and discusses the concepts and findings in a clear and thorough manner. The paper should appeal to a broad audience. It is a good example of the underrepresented information and communications technology-centered literature in health care.

\section{Conflicts of Interest}

None declared.

\section{Reference}

1. van de Wetering R, Versendaal J. Information technology ambidexterity, digital dynamic capability, and knowledge processes as enablers of patient agility: empirical study. JMIRx Med 2021;2(4):e32336 [FREE Full text] [doi: 10.2196/32336]

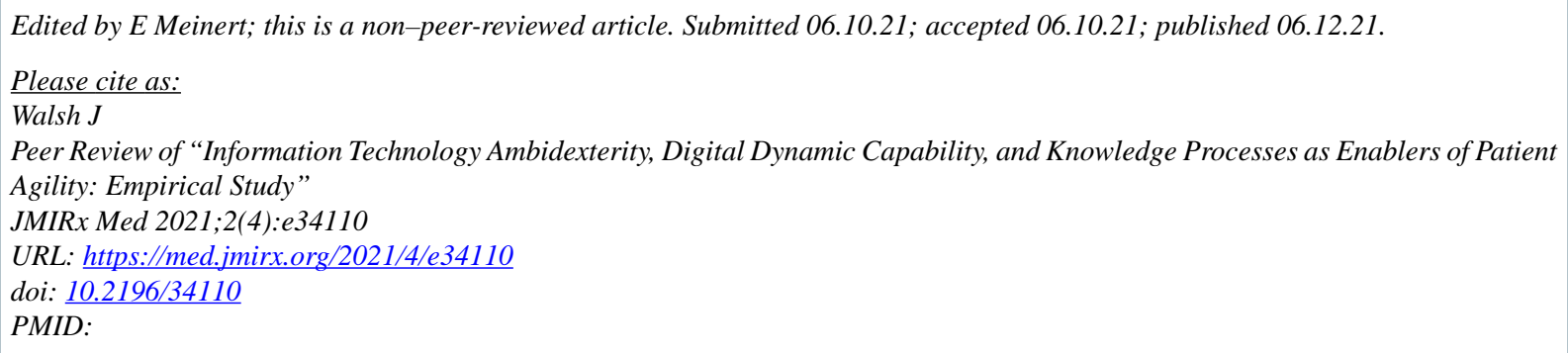

CJoseph Walsh. Originally published in JMIRx Med (https://med.jmirx.org), 06.12.2021. This is an open-access article distributed under the terms of the Creative Commons Attribution License (https://creativecommons.org/licenses/by/4.0/), which permits unrestricted use, distribution, and reproduction in any medium, provided the original work, first published in JMIRx Med, is properly cited. The complete bibliographic information, a link to the original publication on https://med.jmirx.org/, as well as this copyright and license information must be included. 